\title{
Structure and stability upon maternal transmission of common and intermediate FMR1 (Fragile X Mental Retardation 1) alleles in a sample of the Brazilian population
}

\author{
Leonardo P. Capelli, Regina C. Mingroni-Netto and Angela M. Vianna-Morgante \\ Universidade de São Paulo, Instituto de Biociências, Departamento de Biologia, São Paulo, Brazil.
}

\begin{abstract}
In order to investigate the stability of the FMR1 (Fragile X Mental Retardation 1) alleles from the normal population, when maternally inherited, we analyzed 75 mother-to-son transmissions. Sixty-eight alleles fell within the common range with 20-40 CGG repeats, and seven alleles were intermediate, with 41-48 repeats. No change was observed either in the length or in the structure of these repeats upon transmission. Fifty-three alleles were ascertained in different families, and their size distribution was similar to those described for European and European-derived populations, with three peaks of frequency: $66 \%$ of the alleles with $(\mathrm{CGG})_{29},(\mathrm{CGG})_{30}$ or $(\mathrm{CGG})_{31}, 7.5 \%$ with $(\mathrm{CGG})_{20}$, and $5.7 \%$ with $(C G G)_{23}$. Regarding the AGG interspersion pattern, 69.8\% had two AGG repeats, $20.8 \%$ had one, $5.7 \%$ had three and $3.8 \%$ had none. The most common patterns were $10+9+9(30.2 \%), 9+9+9(18.9 \%), 10+9$ $(7.5 \%)$, and $10+9+10(7.5 \%)$. About $70 \%$ of the alleles with up to 40 repeats were linked to the DXS548/FRAXAC1 haplotype 7-3, the most commonly reported in normal populations. Four out of five intermediate alleles were in linkage with the two haplotypes most frequently associated to the FMR1 full mutation, 2-1 and 6-4. These four alleles showed long uninterrupted CGG repeats at the 3' end. The 9+9+22, 9+9+23 and 9+9+28 alleles were linked to the haplotype 2-1, and the 9+37 allele, to the haplotype 6-4. The pattern of AGG interspersion of these alleles and the associated haplotypes were in accordance with the two main pathways toward mutation previously proposed.
\end{abstract}

Key words: FMR1 gene, CGG repeat, fragile X.

Received: January 21, 2004; Accepted: June 8, 2004.

\section{Introduction}

The fragile $\mathrm{X}$ syndrome is the most common $\mathrm{X}$ linked mental retardation disorder affecting $\sim 1$ in 4,000 males and $\sim 1$ in 8,000-9,000 females (Crawford et al., 2001). The Fragile-X Mental Retardation 1 gene (FMR1) was cloned in 1991 (Oberlé et al., 1991; Verkerk et al., 1991; Yu et al., 1991), and the vast majority of fragile-X cases are due to expansions of the polymorphic CGG trinucleotide repeat in the $5^{\text {' }}$-untranslated region of the gene. In the general population, CGG-repeat size varies from 6 to 55. In affected individuals the repeat greatly exceeds 200 and transcription silencing of FMR 1 gene occurs (Pieretti et al., 1991), thus characterizing the full mutation. Alleles with repeats in the $\sim 55-200$ range, which are transcribed, but unstable, may expand to full mutations upon maternal transmission. These are known as premutations. Indeed the boundary between common and premutation al-

Send correspondence to Angela M. Vianna-Morgante. Universidade de São Paulo, Instituto de Biociências, Departamento de Biologia, Caixa Postal 11461, 05422-970, São Paulo, Brazil. Email: avmorgan@ib.usp.br. leles is not well-defined, and constitutes a "gray zone" which includes high-common and low-premutation alleles (Eichler et al., 1994). These intermediate alleles are defined as those with 41 60 repeats, which may or may not be inherited in an unstable manner. (Murray et al., 1997). The smallest allele known to have expanded to a full mutation had a 59 repeat, in a fragile $X$ family (Nolin et al., 2003).

Size is not the only factor implicated in allele instability. The number and position of AGG interspersions determining long uninterrupted CGG arrays at the 3' or 5' ends of the repeat, haplotype background and parental origin have been evoked as predisposing factors leading a common/intermediate allele to progress toward a mutation state (Eichler et al., 1994; Kunst and Warren, 1994; Eichler et al., 1996; Crawford et al., 2000a; Dombrowski et al., 2002; Sullivan et al., 2002; Nolin et al., 2003).

Herein, we report the investigation of the stability of the CGG repeat in mother-son transmissions in a random sample of common and intermediate FMR1 alleles, analyzing repeat sizes, AGG-interspersion patterns, and linked DXS548/FRAXAC1 haplotypes. 


\section{Subjects and Methods}

\section{Subjects}

We studied 135 subjects, 59 female carriers of the FMR1 premutation, one noncarrier female, and their 75 normal sons ascertained in the genetic counseling service of the Departamento de Biologia at the University of São Paulo, in São Paulo city, Brazil. Seventy-four mother-son pairs were selected in fragile $X$ families through a phenotypically normal son who had inherited the normal allele from his carrier mother. In one pair, the mother carried a common and an intermediate allele. All the individuals were genotyped for the diagnosis of their carrier status and genetic counseling. The study was approved by the ethical board of the institution.

\section{Methods}

DNA was obtained from peripheral blood lymphocytes. The FMR 1 CGG-repeat size was determined by PCR using primers $\mathbf{c}$ and $\mathbf{f}(\mathrm{Fu}$ et al., 1991), according to Kenneson et al. (1997), with slight modifications (Mingroni-Netto et al., 2002). For sequencing the CGG repeat, $100 \mathrm{ng}$ of genomic DNA were amplified in a $25 \mu \mathrm{L}$ reaction volume, with $50 \mathrm{mM}$ Tris- $\mathrm{HCl}(\mathrm{pH} 8.0), 50 \mathrm{mM}$ $\mathrm{KCl}, 1 \mathrm{mM}$ DTT, $0.1 \mathrm{mM}$ EDTA, 50\% (v/v) glycerol, $1.4 \mathrm{mM} \mathrm{MgSO} 4,15$ pmoles c and f primers, $400 \mu \mathrm{M}$ each dATP, dGTP, dTTP and dCTP, 1.75 U Platinum Pfx DNA polymerase and $3 \mathrm{X}$ Enhancer (Invitrogen, Carlsbad, USA). Denaturation at $94^{\circ} \mathrm{C}$ for 2 min was followed by 33 cycles of $94^{\circ} \mathrm{C}$ for $30 \mathrm{~s}, 55^{\circ} \mathrm{C}$ for $30 \mathrm{~s}, 68^{\circ} \mathrm{C}$ for $90 \mathrm{~s}$, and final extension at $72{ }^{\circ} \mathrm{C}$ for $10 \mathrm{~min}$. Purification was performed with IN CONCERT TM Rapid PCR Purification System (Invitrogen, Carlsbad, USA), and 60ng of the amplified DNA were re-amplified with 3.2 pmoles of $\mathbf{c}$ or $\mathbf{f}$ primers in $6 \mu \mathrm{L}$ Mix Big Dye (Perkin-Elmer, Foster City, USA). Denaturation at $96^{\circ} \mathrm{C}$ for $10 \mathrm{~s}$ preceded 20 cycles of $98^{\circ} \mathrm{C}$ for $10 \mathrm{~s}$, and a final extension at $60^{\circ} \mathrm{C}$ for $4 \mathrm{~min}$. The samples were purified, precipitated and re-suspended in $12 \mu \mathrm{L}$ Template Suppression Reagent - TSR (Perkin - Elmer, Foster City, USA). Automatic backward and forward sequencing was performed in an ABI Prism 310 Genetic Analyzer (Perkin-Elmer, Foster City, USA). PCR amplifications of FRAXAC1 and DXS548 alleles were performed as previously described (Mingroni-Netto et al., 1999). The allele nomenclature followed Macpherson et al. (1994).

\section{Results and Discussion}

The stability of the FMR1 CGG repeat was evaluated in 75 mother-son transmissions: 46 mother-one son, 11 mother-two son (22), one mother-three son (3), and one mother-four son (4) transmissions. Fifty-three of these alleles were ascertained in different families, and their CGG repeat ranged in size from 20 to 48 : $90.6 \%$ (48/53) had $\mathrm{CGG} \leq 40$, and $9.4 \%(5 / 53)$ were in the intermediate range (Figure 1).

The distribution of the CGG repeat sizes varies in different ethnic groups. The population of São Paulo city is ethnically heterogeneous and its composition has been in-

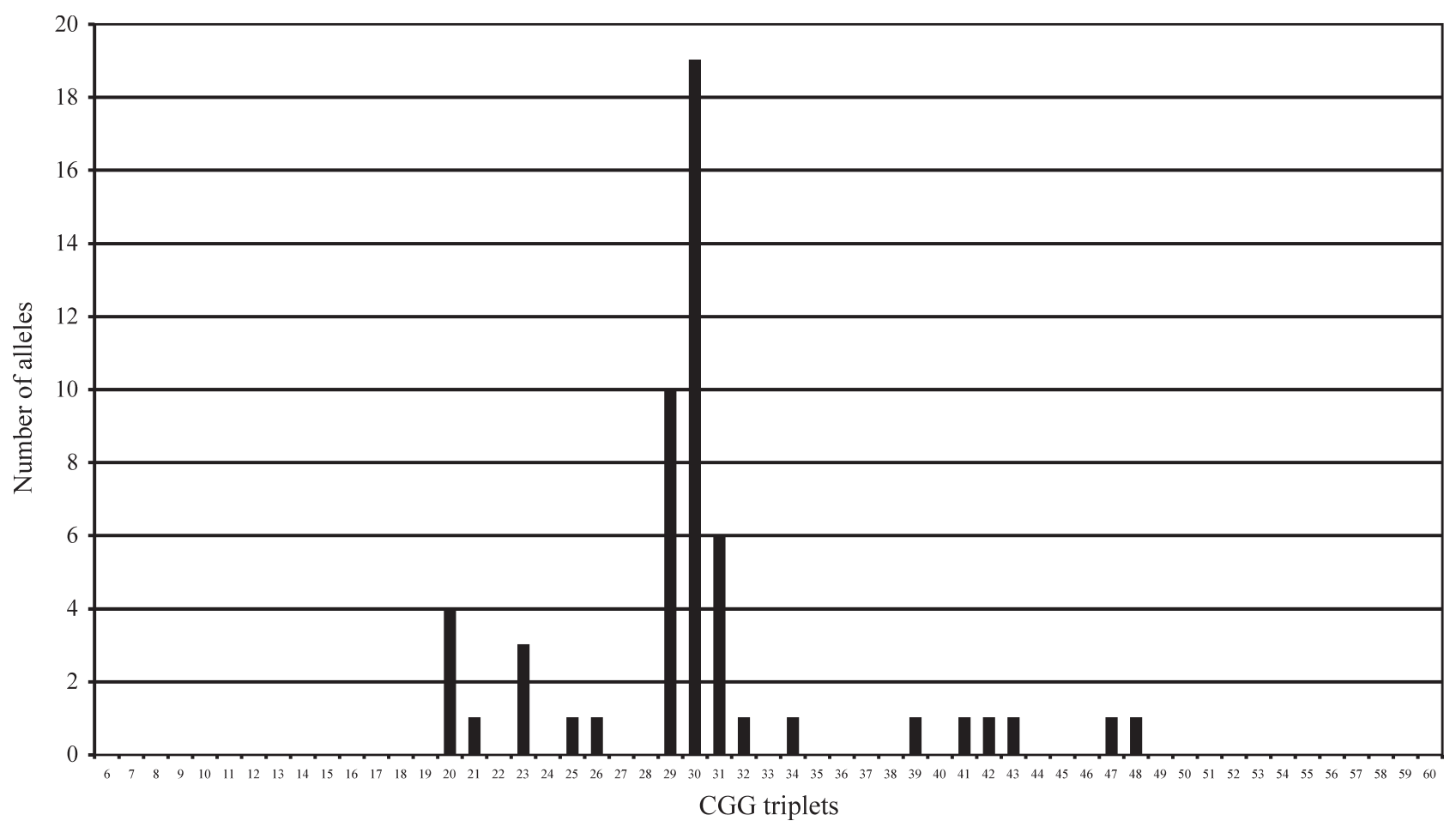

Figure 1 - FMR1 alleles according to the length of the CGG repeat in 53 unrelated males from the population of São Paulo. 
fluenced by migrations since the $16^{\text {th }}$ century, with contributions from Europeans, African slaves, Asians, and in a smaller proportion of native Indians. Our sample was predominantly formed by individuals of European ancestry, and accordingly, the frequency distribution of the alleles followed those observed in European and Europeanderived populations, including our previous study of the São Paulo city population: a significant peak of frequency of alleles with $(\mathrm{CGG})_{29-31}$, a second peak around $(\mathrm{CGG})_{20}$, and a smaller third peak of alleles with $(\mathrm{CGG})_{23}$, the $(\mathrm{CGG})_{30}$ allele being the most frequent, (Chiurazzi et al., 1996; Mingroni-Netto et al., 2002). The studied alleles can therefore be considered as representing a random sample.

\section{The stability of the repeat size upon maternal transmission}

In $62.7 \%$ of the 75 transmissions (47/75) the alleles most frequent in the population were the $(\mathrm{CGG})_{29}-(\mathrm{CGG})_{31}$. Smaller alleles, with 20-26 triplets accounted for $24 \%$ of the transmissions $(18 / 75)$, and the $(\mathrm{CGG})_{20}$ was the most frequent $\left(44.4 \%\right.$ - 8/18). Larger normal alleles, $(\mathrm{CGG})_{32}$ $(\mathrm{CGG})_{40}$, represented $4 \%$ of the transmissions $(3 / 75)$. In seven transmissions $(9.3 \%$ - $7 / 75)$ the alleles were in the intermediate range. No changes were observed in the size of these alleles upon maternal transmission ( $95 \%$ confidential interval: 0 - 4.8\%); (Table 1).

These results are in accordance with those obtained in other studies, pointing to the stability of the CGG-repeat size up to 40 , when maternally inherited, with small changes observed in less than $1 \%$ of the cases (Murray et

Table 1 - Distribution of 75 stable maternal transmissions of FMR1 normal and intermediate alleles.

\begin{tabular}{lccc}
\hline$(\mathrm{CGG})_{\mathrm{n}}$ & & Number of transmissions \\
\cline { 1 - 2 } Maternal allele & Son allele & $\mathrm{N}=75$ \\
\hline 20 & 20 & 8 \\
21 & 21 & 1 \\
23 & 23 & 6 \\
25 & 25 & 1 \\
26 & 26 & 2 \\
29 & 29 & 12 \\
30 & 30 & 22 \\
31 & 31 & 13 \\
32 & 32 & 1 \\
34 & 34 & 1 \\
39 & 39 & 1 \\
41 & 41 & 1 \\
42 & 42 & 1 \\
43 & 43 & 1 \\
47 & 47 & 2 \\
48 & 48 & 2 \\
\hline
\end{tabular}

al., 1997; Youings et al., 2000; Sullivan et al., 2002). The seven intermediate allele transmissions found in our study were all stable. Changes in intermediate range alleles, however, are more prone to occur, with a mutation rate of about $3 \%$ in maternal transmissions (Murray et al., 1997; Youings et al., 2000; Sullivan et al., 2002). The tendency of these alleles to expand is directly related to the size of the repeat (Nolin et al., 2003). Interestingly, common and intermediate alleles are less stable when transmitted through males than through females, in clear contrast with the premutated alleles (Sullivan et al., 2002). Both selection against sperm with increasing repeat length and a different mutational mechanism for alleles at the common/intermediate range are possible explanations.

\section{CGG-repeat structure}

The AGG-interspersion pattern of the CGG repeat was determined by sequencing all the 75 alleles from the normal males. The sequences of the alleles with proven common ancestry showed that no structure change had occurred within families. Among the 53 unrelated alleles, 21 patterns were identified (Table 2). In the most frequent, the sequence presented two AGG interruptions, every nine or ten CGG $(69.8 \%$; 37/53). At the 3' end, the last AGG interruption was most often followed by a nine-CGG array. Among the most frequent allele sizes, $(\mathrm{CGG})_{30}$ had characteristically (16/19) the 10+9+9 structure (+ standing for AGG), $(\mathrm{CGG})_{29}$, the structure $9+9+9(10 / 10)$, and $(\mathrm{CGG})_{31}$, $10+9+10(4 / 6)$. All four $(\mathrm{CGG})_{20}$ alleles were $10+9$. Alleles with three AGG interspersions represented $5.7 \%(3 / 53)$ of the sample - one $(\mathrm{CGG})_{30}-10+7+1+9$, one $(\mathrm{CGG})_{39}$ $9+9+9+9$ and one intermediate allele $(\mathrm{CGG})_{41}$ $9+10+10+9$. Alleles with pure CGG triplets accounted for $3.8 \%(2 / 53)$ of the sequences - one (CGG) ${ }_{23}$ and one $(\mathrm{CGG})_{26}$, all alleles $\leq 30$. Eleven alleles $(20.8 \%)$ had one AGG interspersion - four $(\mathrm{CGG})_{20}$, one $(\mathrm{CGG})_{21}$, two $(\mathrm{CGG})_{23}$, one $(\mathrm{CGG})_{25}$, one $(\mathrm{CGG})_{30}$, one $(\mathrm{CGG})_{34}$ and one $(\mathrm{CGG})_{47}$, therefore, only two alleles $\geq 30$. Four of these alleles had more than $10 \mathrm{CGG}$ at the 5' end, before the first AGG interspersion: two $(\mathrm{CGG})_{23}-13+9$, one $(\mathrm{CGG})_{25}-$ $15+9$ and one $(\mathrm{CGG})_{30}-20+9$. Two alleles had 24 and 37 CGG uninterrupted arrays at the 3 ' end: $(\mathrm{CGG})_{34}-9+24$ and $(\mathrm{CGG})_{47}-9+37$.

Eichler et al. (1994) and Eichler et al. (1995) were the first to report that the majority of CGG repeats presented two AGG interspersions, and that large uninterrupted CGG sequences were at the $3^{\prime}$ end, pointing to polarity in instability. The loss of the most 3' AGG or its conversion to CGG was proposed as predisposing to instability. In African-Americans, however, Crawford et al. (2000b) identified a large uninterrupted CGG repeat at the $5^{\prime}$ end as a probable predisposing factor to instability, thus disclosing a population-dependent pathway to mutation. 
Table 2 - Distribution of 53 FMR1 common and intermediate alleles, according to the length of the repeat, AGG interspersion patterns, and linked DXS542/FRAXAC1 haplotypes.

\begin{tabular}{|c|c|c|c|c|c|c|c|c|c|c|c|c|c|c|c|c|c|c|}
\hline \multirow{2}{*}{$\begin{array}{l}\text { AGG interrup- } \\
\text { tion pattern* }\end{array}$} & \multirow{2}{*}{$\begin{array}{c}\text { DXS548/FRAXA } \\
\text { C1 haplotype }\end{array}$} & \multicolumn{16}{|c|}{ Number of CGG triplets } & \multirow{2}{*}{$\begin{array}{l}\text { Total of } \\
\text { alleles }\end{array}$} \\
\hline & & 20 & 21 & 23 & 25 & 26 & 29 & 30 & 31 & 32 & 34 & 39 & 41 & 42 & 43 & 47 & 48 & \\
\hline $10+9$ & $7-3$ & 4 & & & & & & & & & & & & & & & & 4 \\
\hline $10+10$ & $7-2$ & & 1 & & & & & & & & & & & & & & & 1 \\
\hline 23 & $7-3$ & & & 1 & & & & & & & & & & & & & & 1 \\
\hline \multirow[t]{2}{*}{$13+9$} & $7-2$ & & & 1 & & & & & & & & & & & & & & 1 \\
\hline & $7-3$ & & & 1 & & & & & & & & & & & & & & 1 \\
\hline $15+9$ & $7-3$ & & & & 1 & & & & & & & & & & & & & 1 \\
\hline 26 & $7-3$ & & & & & 1 & & & & & & & & & & & & 1 \\
\hline \multirow{6}{*}{$9+9+9$} & $7-3$ & & & & & & 3 & & & & & & & & & & & 3 \\
\hline & $7-2$ & & & & & & 2 & & & & & & & & & & & 2 \\
\hline & $2-4$ & & & & & & 2 & & & & & & & & & & & 2 \\
\hline & $7-4$ & & & & & & 1 & & & & & & & & & & & 1 \\
\hline & $7-6$ & & & & & & 1 & & & & & & & & & & & 1 \\
\hline & $5-4$ & & & & & & 1 & & & & & & & & & & & 1 \\
\hline \multirow[t]{3}{*}{$10+9+9$} & $7-3$ & & & & & & & 14 & & & & & & & & & & 14 \\
\hline & $6-3$ & & & & & & & 1 & & & & & & & & & & 1 \\
\hline & $8-3$ & & & & & & & 1 & & & & & & & & & & 1 \\
\hline $20+9$ & $7-3$ & & & & & & & 1 & & & & & & & & & & 1 \\
\hline $9+9+10$ & $5-2$ & & & & & & & 1 & & & & & & & & & & 1 \\
\hline $10+7+1+9$ & $7-3$ & & & & & & & 1 & & & & & & & & & & 1 \\
\hline $10+9+10$ & $7-3$ & & & & & & & & 4 & & & & & & & & & 4 \\
\hline $10+10+9$ & $7-1$ & & & & & & & & 2 & & & & & & & & & 2 \\
\hline $9+9+12$ & $7-3$ & & & & & & & & & 1 & & & & & & & & 1 \\
\hline $9+24$ & $7-3$ & & & & & & & & & & 1 & & & & & & & 1 \\
\hline $9+9+9+9$ & $2-1$ & & & & & & & & & & & 1 & & & & & & 1 \\
\hline $9+10+10+9$ & $7-3$ & & & & & & & & & & & & 1 & & & & & 1 \\
\hline $9+9+22$ & $2-1$ & & & & & & & & & & & & & 1 & & & & 1 \\
\hline $9+9+23$ & $2-1$ & & & & & & & & & & & & & & 1 & & & 1 \\
\hline $9+37$ & $6-4$ & & & & & & & & & & & & & & & 1 & & 1 \\
\hline $9+9+28$ & $2-1$ & & & & & & & & & & & & & & & & 1 & 1 \\
\hline Total of alleles & & 4 & 1 & 3 & 1 & 1 & 10 & 19 & 6 & 1 & 1 & 1 & 1 & 1 & 1 & 1 & 1 & 53 \\
\hline
\end{tabular}

*Numbers $=$ CGG triplets; $+=$ AGG.

\section{AGG-interspersion patterns and linked DXS548/FRAXAC1 haplotypes}

The DXS548 and FRAXAC1 microsatellite loci are tightly linked to the FMRI gene (Richards et al., 1991; Riggins et al., 1992). The 7-3 (194 bp/154 bp) haplotype was the most frequent in our sample $(34 / 53 ; 64.1 \%)$, as observed on $50 \%-70 \%$ of the chromosomes in European and European-derived populations (Chiurazzi et al., 1996; Peixoto et al., 1998; Mingroni-Netto et al., 1999; Crawford et al., 2000a). Haplotypes frequently associated to fragile $X$ chromosomes in these populations $(2-1,204 \mathrm{bp} / 158 \mathrm{bp}$, and $6-4,196 \mathrm{bp} / 152 \mathrm{bp}$ ) represented $9.4 \%$ of our sample. We did not observe the haplotypes 4-4 (200 bp/152 bp) or 3-4 (202 $\mathrm{bp} / 152 \mathrm{bp}$ ), reported to be frequent on fragile $\mathrm{X}$ chromosomes of African-Americans (Crawford et al., 2000a).

We analyzed the 53 unrelated alleles regarding the pattern of AGG-interspersion and the linked DXS548/FRAXAC1 haplotype (Table 2). Around 47\% $(25 / 53)$ of the chromosomes had the 7-3 haplotype associated with the commonest normal alleles: $(\mathrm{CGG})_{30}$ 10+9+9; $(\mathrm{CGG})_{31}-10+9+10 ;(\mathrm{CGG})_{29}-9+9+9$, and $(\mathrm{CGG})_{20}-10+9$. The most frequent association was the pattern $10+9+9$ and the $7-3$ haplotype, on more than $20 \%$ of the chromosomes, as already reported (Eichler et al., 1996; Gunter et al., 1998; Ennis et al., 2001). The pattern 9+9+9 was linked to the highest number of different haplotypes (six), and it was associated with the 7-3 haplotype only on 
$5.6 \%(3 / 53)$ of the chromosomes. Indeed, the observation that in African-Americans the 9+9+9 repeat was associated with the highest haplotype diversity had already suggested that this is probably the ancestral CGG repeat structure (Crawford et al., 2000b).

Among the 48 alleles with up to 40 triplets, the fragile $\mathrm{X}$ haplotype 2-1 was observed only once linked to a $(\mathrm{CGG})_{39}-9+9+9+9$, and the haplotype 6-4 was not found. Eight of these 48 common alleles had uninterrupted CGG sequences with more than 10 triplets, and seven $(87.5 \%)$ were linked to the commonest 7-3 haplotype: two pure CGG sequence alleles - $(\mathrm{CGG})_{23}$ and $(\mathrm{CGG})_{26}$; one $(\mathrm{CGG})_{23}$ - 13+9; one $(\mathrm{CGG})_{25}-15+9$; one $(\mathrm{CGG})_{30}-20+9$; one $(\mathrm{CGG})_{32}-9+9+12$, and one $(\mathrm{CGG})_{34}-9+24$. The other allele, $(\mathrm{CGG})_{23}-13+9$, was linked to the haplotype 7-2 (194 $\mathrm{bp} / 156 \mathrm{bp})$. None of these haplotypes had been significantly represented on reported fragile $\mathrm{X}$ chromosomes.

On the other hand, four out of the five intermediate alleles were linked to the haplotypes most frequently associated with fragile $\mathrm{X}$ chromosomes. They presented large uninterrupted sequences at the $3^{\prime}$ 'end: three alleles $(\mathrm{CGG})_{42},(\mathrm{CGG})_{43}$ and $(\mathrm{CGG})_{48}$, associated with the 2-1 haplotype, showed the pattern $9+9+X$, with $X=22,23$ and 28 CGG repeats. The allele $(\mathrm{CGG})_{47}$ had a $9+37$ pattern, and was associated with the 6-4 haplotype. The remaining intermediate allele, $(\mathrm{CGG})_{41}$, had three $\mathrm{AGG}$ interspersions $(9+10+10+9)$, and was linked to the 7-3 haplotype.

Kunst and Warren (1994) first reported that alleles with long uninterrupted CGG repeats at the 3' end were in linkage disequilibrium with the haplotypes most frequently associated with the fragile $\mathrm{X}$ chromosomes, thus constituting the pool of alleles from which the expanded mutated alleles were derived. Based on the structure of the repeats, and the linked haplotypes, Eichler et al. (1996) proposed two main mutational pathways in the origin of the fragile $\mathrm{X}$ mutation. In ancestral CGG repeats with an asymmetrical structure, associated with the 6-4 haplotype, the recurrent loss of AGG interruptions would lead to a relatively rapid progress to the mutation. The alleles linked to the 2-1 haplotype, which maintained two AGG interspersions, would generate larger alleles by gradual increases in CGG repeats distal to the most 3' AGG. More recently, a study of the English population revealed that alleles associated with the 6-4 haplotype showed the structure $9+X+Y(X>9 C G G$ triplets and $\mathrm{Y}$, any sequence size) or $9+\mathrm{X}$; in turn, alleles on 2-1 haplotypes had patterns 9+9+X (Ennis et al., 2001). Again in accordance with the two-mutation-pathway hypothesis, the intermediate alleles linked to 2-1 haplotype in our sample had the $9+9+X$ pattern, and the $9+37$ structure was associated with the 6-4 haplotype.

Our data confirms that common FMR1 alleles $(\mathrm{CGG} \leq 40)$ are quite stable upon maternal transmission. The most frequent DXS548/FRAXAC1 haplotypes on fragile $\mathrm{X}$ chromosomes were not found to be associated with the common alleles with structures that would favor expansions, such as pure CGG sequences or 5' or 3' uninterrupted $C G G \geq 20$. On the other hand, uninterrupted CGG sequences of similar sizes on alleles with more than 40 triplets were always associated with fragile $\mathrm{X}$ haplotypes. Whether the linked haplotype or other cis-acting sequence somehow influence or not the tendency of these alleles to expand remains unclear.

\section{Acknowledgments}

We are indebted to MS Silvia S. Costa, MS Cláudia B. Angelli, Ms. Maria Cristina F. Costa and Ms. Fátima P. C. Baptista for technical assistance. This work was supported by FAPESP and CNPq.

\section{References}

Chiurazzi P, Macpherson J, Sherman S and Neri G (1996) Significance of linkage disequilibrium between the fragile $\mathrm{X}$ locus and its flanking markers. Am J Med Genet 64:203-208.

Crawford DC, Schwartz CE, Meadows KL, Newman JL, Taft LF, Gunter C, Brown WT, Carpenter NJ, Howard-Peebles PN, Monaghan KG, Nolin SL, Reiss AL, Feldman GL, Rohlfs EM, Warren ST and Sherman SL (2000a) Survey of the fragile $\mathrm{X}$ syndrome CGG repeat and the short-tandem-repeat and single-nucleotide-polymorphism haplotypes in an African American population. Am J Hum Genet. 66:480-493.

Crawford DC, Zhang F, Wilson B, Warren ST and Sherman SL (2000b) Fragile X CGG repeat structures among African-Americans: Identification of a novel factor responsible for repeat instability. Hum Mol Genet 9:1759-1769.

Crawford DC, Acuna JM and Sherman SL (2001) FMR1 and the fragile $\mathrm{X}$ syndrome: Human genome epidemiology review. Genet Med 3:359-371.

Dombrowski C, Levesque S, Morel ML, Rouillard P, Morgan K and Rousseau F (2002) Premutation and intermediate-size FMR1 alleles in 10572 males from the general population: Loss of an AGG interruption is a late event in the generation of fragile X syndrome alleles. Hum Mol Genet 11:371-378.

Eichler EE, Holden JJ, Popovich BW, Reiss AL, Snow K, Thibodeau SN, Richards CS, Ward PA and Nelson DL (1994) Length of uninterrupted CGG repeats determines instability in the FMR1 gene. Nat Genet 8:88-94.

Eichler EE, Hammond HA, Macpherson JN, Ward PA and Nelson DL (1995) Population survey of the human FMR1 CGG repeat substructure suggests biased polarity for the loss of AGG interruptions. Hum Mol Genet 4:2199-2208.

Eichler EE, Macpherson JN, Murray A, Jacobs PA, Chakravarti A and Nelson DL (1996) Haplotype and interspersion analysis of the FMR 1 CGG repeat identifies two different mutational pathways for the origin of the fragile $\mathrm{X}$ syndrome. Hum Mol Genet 5:319-330.

Ennis S, Murray A and Morton NE (2001) Haplotypic determinants of instability in the FRAX region: Concatenated mutation or founder effect? Hum Mut 18:61-69.

Fu YH, Kuhl DP, Pizzuti A, Pieretti M, Sutcliffe JS, Richards S, Verkerk AJ, Holden JJ, Fenwick RG Jr and Warren ST (1991) Variation of the CGG repeat at the fragile X site results in genetic instability: Resolution of the Sherman paradox. Cell 67:1047-1058. 
Gunter C, Paradee W, Crawford DC, Meadows KA, Newman J, Kunst CB, Nelson DL, Schwartz C, Murray A, Macpherson JN, Sherman SL and Warren ST (1998) Re-examination of factors associated with expansion of CGG repeats using a single nucleotide polymorphism in FMR1. Hum Mol Genet 7:1935-1946.

Kenneson A, Cramer DW and Warren ST (1997) Fragile X premutations are not a major cause of early menopause. Am J Hum Genet 61:1362-1369.

Kunst CB and Warren ST (1994) Cryptic and polar variation of the fragile $\mathrm{X}$ repeat could result in predisposing normal alleles. Cell 77:853-861.

Macpherson JN, Bullman H, Youings SA and Jacobs PA (1994) Insert size and flanking haplotype in fragile $\mathrm{X}$ and normal populations: Possible multiple origins for the fragile $\mathrm{X}$ mutation. Hum Mol Genet 3:399-405.

Mingroni-Netto RC, Costa SS, Angeli CB and Vianna-Morgante AM (1999) DXS548/FRAXAC1 haplotypes in fragile X chromosomes in the Brazilian population. Am J Med Genet 84:204-207.

Mingroni-Netto RC, Angeli CB, Auricchio MT, Leal-Mesquita ER, Ribeiro-Dos-Santos AK, Ferrari I, Hutz MH, Salzano FM, Hill K, Hurtado AM and Vianna-Morgante AM (2002) Distribution of CGG repeats and FRAXAC1/DXS548 alleles in South American populations. Am J Med Genet 111:243-252.

Murray A, Macpherson JN, Pound MC, Sharrock A, Youings SA, Dennis NR, McKechnie N, Linehan P, Morton NE and Jacobs PA (1997) The role of size, sequence and haplotype in the stability of FRAXA and FRAXE alleles during transmission. Hum Mol Genet 6:173-184.

Nolin SL, Brown WT, Glicksman A, Houck GE Jr, Gargano AD, Sullivan A, Biancalana V, Brondum-Nielsen K, Hjalgrim H, Holinski-Feder E, Kooy F, Longshore J, Macpherson J, Mandel JL, Matthijs G, Rousseau F, Steinbach P, Vaisanen ML, von Koskull H and Sherman SL (2003) Expansion of the fragile X CGG repeat in females with premutation or intermediate alleles. Am J Hum Genet 72:454-464.

Oberlé I, Rousseau F, Heitz D, Kretz C, Devys D, Hanauer A, Boue J, Bertheas MF and Mandel JL (1991) Instability of a 550-base pair DNA segment and abnormal methylation in fragile X syndrome. Science 252:1097-1102.

Peixoto A, dos Santos MR, Seruca R, Amorim A, Castedo S (1998) Analysis of FMR1 and flanking microsatellite markers in normal and fragile X chromosomes in Portugal: Evidence for a "protector" haplotype. Eur J Hum Genet 6:518-522.

Pieretti M, Zhang FP, Fu YH, Warren ST, Oostra BA, Caskey CT and Nelson DL (1991) Absence of expression of the FMR-1 gene in fragile X syndrome. Cell 66:817-822.

Richards RI, Holman K, Kozman H, Kremer E, Lynch M, Pritchard M, Yu S, Mulley J and Sutherland GR (1991) Fragile $\mathrm{X}$ syndrome: Genetic localisation by linkage mapping of two microsatellite repeats FRAXAC1 and FRAXAC2 which immediately flank the fragile site. J Med Genet 28:818-823.

Riggins GJ, Sherman SL, Oostra BA, Sutcliffe JS, Feitell D, Nelson DL, van Oost BA, Smits AP, Ramos FJ and Pfendner E (1992) Characterization of a highly polymorphic dinucleotide repeat $150 \mathrm{~Kb}$ proximal to the fragile $\mathrm{X}$ site. Am J Med Genet 43:237-243.

Sullivan AK, Crawford DC, Scott EH, Leslie ML and Sherman SL (2002) Paternally transmitted FMR1 alleles are less stable than maternally transmitted alleles in the common and intermediate size range. Am J Hum Genet 70:1532-1544.

Verkerk AJ, Pieretti M, Sutcliffe JS, Fu YH, Kuhl DP, Pizzuti A, Reiner O, Richards S, Victoria MF and Zhang FP (1991) Identification of a gene (FMR-1) containing a CGG repeat coincident with a breakpoint cluster region exhibiting length variation in fragile X syndrome. Cell 65:905-914.

Youings SA, Murray A, Dennis N, Ennis S, Lewis C, McKechnie N, Pound M, Sharrock A and Jacobs P (2000) FRAXA and FRAXE: The results of a five year survey. J Med Genet 37:415-421.

Yu S, Pritchard M, Kremer E, Lynch M, Nancarrow J, Baker E, Holman K, Mulley JC, Warren ST and Schlessinger D (1991) Fragile X genotype characterized by an unstable region of DNA. Science 252:1179-1181.

Associate Editor: Francisco Mauro Salzano 